\title{
Postdigital Possibilities: Operaismo, Co-research, and Educational Inquiry
}

\section{Patrick Carmichael ${ }^{1}$ (D)}

Published online: 13 December 2019

(C) The Author(s) 2019

\begin{abstract}
There are parallels between the post-Marxist traditions of operaismo (workerism) and autonomism and emerging ideas about the 'postdigital'. Operaist analyses and approaches, and particularly the work of Romano Alquati on co-research, have the potential to contribute to discourses as to what might be involved in postdigital inquiry in educational settings, and to better understand of critical data literacies. For such educational inquiry to evolve into a comprehensive strategy of 'co-research', it is argued that what is needed are models of teacher inquiry with the potential to challenge dominant rhetorics, to support emancipatory research and development, and to establish the postdigital as a counter-hegemonic educational programme.
\end{abstract}

Keywords Operaismo $\cdot$ Workers' inquiry $\cdot$ Co-research $\cdot$ Postdigital $\cdot$ Data literacies

\section{Introduction}

This article discusses how the development of thinking about the postdigital in education might usefully engage with post-Marxist operaist (workerist) and autonomist theory and praxis. The idea of the postdigital does not imply that the time has arrived when we have moved beyond the digital, but rather that we turn our attention to the concept of the digital and the ways in which it is incorporated into systems, subjectivities, practice, and language. By analogy with the postmodern, the posthuman or, for that matter, post-Marxism, it involves the critical re-evaluation not only of specific phenomena, but also of the theories, methodologies, and practices that have hitherto been used to explore the digital as well as those that the digital has, in turn, enabled and encouraged.

Alexenberg (2011), in a widely cited description of the postdigital in the context of the arts, characterizes it as involving:

Patrick Carmichael

patrick.carmichael@beds.ac.uk

1 Faculty of Education and Sport, University of Bedfordshire, Bedfordshire, UK 
... interplay between digital, biological, cultural, and spiritual systems, between cyberspace and real space, between embodied media and mixed reality in social and physical communication, between high tech and high touch experiences, between visual, haptic, auditory, and kinesthetic media experiences, between virtual and augmented reality, between roots and globalization, between autoethnography and community narrative. (Alexenberg 2011: 35)

This idea of interplay and entanglement is evident in more recent accounts of what postdigital perspectives or sensitivities in education might entail. Ryberg et al. (2018) discuss complex orchestrations entangling space and place, technologies, and social interactions, and Jandrić et al. (2018) characterize postdigital education as an untidy yet generative space with the capacity to challenge notions of the digital, the virtual and the online, and to rupture existing theories and their continuation.

Operaismo, which is conventionally translated as 'workerism', on the other hand, developed as a trend on the Italian left in the early 1960s. A radical tendency rather than a theoretically or politically unified and continuous tradition, it evolved into the 'autonomist' tradition on the left that has been highly influential in providing critical analyses of globalization and neoliberalism; of the regimes of 'austerity' imposed by governments in the early twenty-first century; and the ways in which work and workplaces, have changed as a result of these. This tendency is sometimes described as 'compositionist', stemming from a central tenet of operaist thinking and political action. This was the argument that initial concerns about 'technical composition' (the subjective experience of work, the technological and supervisory mechanisms that shape that experience, and how these contribute to the composition of capital) could inform awareness of broader 'political composition' involving identification of class interests, activism, and opportunities for political activity beyond the workplace (Wright 2002). Understanding one's subjective experience though 'workers' inquiry' was, therefore, a point of departure for broader social and political inquiry. The paper will look in particular at the work of Romano Alquati on conricerca (co-research) and discuss how the theoretical foci identified and research approaches developed by Alquati and other operaisti might provide a means of broadening and orientating educational inquiry towards a counter-hegemonic and emancipatory instantiation of the postdigital.

The idea of workers undertaking research into their own experience will of course not be unfamiliar to those involved in the participatory action research tradition in education and other fields, and the advocates of inquiry informed by radical pedagogy have long argued that it has a scope and impact far beyond educational institutions (Giroux and McLaren 1987; Freire 1998). But operaist workers' inquiry and coresearch have distinctive features that set them apart from action research, and which, as we will discuss later, are of particular relevance to contemporary educational systems. That said, readers may be wondering how the experience of political activists working in factories in Italy in the mid 1960s have any bearing on educational practice and inquiry over half a century later. Part of the answer is that the operaists were active at a time when a range of social and technological factors were disrupting existing workplaces, as well as social structures and relations more broadly. While the context is different, contemporary workplaces, including educational settings, are currently being disrupted to at least the same extent: something that is reflected in renewed interest in operaismo and the emergence of new 'post-operaist' thinking and political action. 
Furthermore, if one subscribes to the idea that we are currently experiencing a 'fourth industrial revolution' (Schwab 2016), then Marx, in his early writings, reflected on the first such revolution (which involved the supplanting of artisan and craft production by industrial techniques), while his later writings documented the second (which was characterized by the rise of large-scale mechanized factories). Operaismo drew on the later Marx in its analysis of the third industrial revolution (which saw the introduction of computers into workplaces, and changes in the nature and distribution of work). Finally, both contemporary post-operaismo and ideas about the postdigital represent responses to a fourth industrial revolution characterized by networked informational labour, automation, artificial intelligence, and what Schwab describes as 'biophysical' systems combining biological, physical and informational elements.

\section{Operaismo, Autonomia, Post-Operaismo}

Historical accounts of operaismo and its successors have conventionally identified it as beginning with the publication of the first issue of the journal Quaderni Rossi (Red Notebooks) in 1962 (Tronti 2012), although more comprehensive analyses identify antecedents on the left both in Europe and in the USA (Haider and Mohandesi 2013; Roggero et al. 2002; Wright 2002; Wright 2007a), and trace how ideas from this first phase of operaist activity were incorporated into later autonomist and 'post-operaist' thinking and political organization.

The intention, Tronti writes, was:

... not to be drawn into a minute re-examination of original texts, but rather to explore the realities of everyday working life, particularly in new industries in which precarity and fragmentation were the norm, and in contexts where automation was changing workers' lives both within and beyond their workplaces. This in turn informed new self-organized social formations, and forms of activism more militant than those organized through established employer-worker committees. (Tronti 2010: 186)

That said, an important underpinning of the distinctive theoretical insights of operaismo was a critical reading of Marx's Grundrisse written in 1857-1861, (first published in German in 1939 and English in 1973) (Marx 1973) which led to a position that, rather than the working class being passive and shaped by capitalist development, it was working class struggle and self-actualisation that drove the successive restructuring of capitalism. This in turn informed the development of a strategy of refusal of labour accompanied by explorations of alternative ways of being, outside capitalist cycles of production and consumption: what Thoburn calls '... a propulsive force toward inventive practice within and against the productive regimes of the social factory' (Thoburn 2003: 111). The 'social factory' here refers to the expansion of capitalist social relations beyond the factory and into society more widely, including, of course, educational settings (Tronti 1962; Palazzo 2014).

While operaismo is generally regarded as having been a specific and ultimately short-lived phase within the broader development of autonomist Marxism (Wright 2002; Wright 2007b; Tronti 2012), concepts from 1960's operaismo have persisted 
and been adapted in response to emerging phenomena (Brophy 2004). The social factory is understood to be broader than the immediate environs of the workplace and, in contemporary society, the 'socialized worker' exists in a 'diffuse factory' (Negri 1978: 94; Negri 2005) in which work is packetized and distributed with the aid of network technologies into society more widely. Later autonomist writings also offer accounts couched in terms of smoothness, striation and territorialization: Negri and Hardt, following Deleuze and Guattari, suggest that what exists now is a globalized and deterritorialized capitalism that presents as a 'smooth space across which subjectivities glide and which has the capacity to absorb and disperse resistance (Hardt and Negri 2001: 198). More broadly, the work of Negri and Hardt has been used to theorize how digital networks are intrinsic to the new social formations and movements that reflect the interests of a diverse global 'multitude' (Hardt and Negri 2001; Hardt and Negri 2006). Autonomism has therefore been used as a framing of broad social movements in which class identity and organization are of lesser importance than causes such as antiglobalization, social justice or action on climate change (Cuninghame 2010). Reflecting on the decline of the industrial working class and the rise of new political collectivities, Negri suggests that the metropolis rather than the individual workplace is the new focus of political activity and accordingly calls for new forms of 'militant metropolitan inquiry' (Negri 2018: 52).

Recently, there has been a marked resurgence of interest in the ideas and approaches of the original operaists in relation to current patterns of 'fourth industrial revolution' automation; reduction or marketisation of public services as part of 'austerity' programmes; and increasing levels of worker surveillance and precarity. A wave of 'new' operaist, class-compositionist analysis has drawn on ideas about social movements and social composition but has refocussed attention on the subjective experience of work often 'diffuse' in workplaces and in 'platform' working enabled by digital networks and contingent on widespread use of data analytics (Scholz 2017; Srnicek 2017). Examples include studies of work in call centres (Woodcock 2016), food delivery (Cant 2019), hospitality (Murray 2014), logistics (Curcio 2014; Delfanti 2018), and care work (Hall 2018).

These currents of thought and activism, with their emphasis on changes in the nature and distribution of work, and its intrusions into all other aspects of social life, can be read as a 'subversive counterinterpretation of the information revolution' (DyerWitheford 1999: 64). They are premised neither on the idea that any particular technological development is inherently progressive or repressive, nor that technologies, data or methods are neutral tools. What this meant, the operaist theorist Raniero Panzieri wrote in 1964, was that 'faced by capital's interweaving of technology and power (all'intreccio capitalistico di tecnica e potere), the prospect of an alternative (i.e. working-class) use of technology can clearly not be based on a pure and simple reversal of the relations of production' (Panzieri 1994a: 54). Analysis and counter-hegemonic activity therefore had to involve disentanglement, reworking, and creative (re)appropriation through the formation of new collectivities or, to use Panzieri's language, 'unweaving' and 'reweaving'.

The contention here, then, is that operaist ideas from the 1960s onwards can provide useful contributions to the theoretical framing of the postdigital, and that contemporary post-operaist ideas and activities are intrinsically postdigital in character. And, like the postdigital, the operaist tradition has also involved the re-examination of the adequacy 
and applicability of existing theoretical frameworks in the light of technological developments, and the new subjectivities and relationships with which they are associated (Dyer-Witheford et al. 2019). But what operaist and post-operaist approaches also bring that is of particular value in the context of the emerging post digital research agenda - in education and more widely - is a commitment to self-directed and selfelucidating inquiry, not as something that is incidental or subordinate to theorybuilding, but rather that is a critical aspect of radical praxis.

\section{Workers' Inquiry and Co-research}

A central element of the original operaist project, documented in Quaderni Rossi, was the idea of 'workers' inquiry' as a means of exploring subjective experiences of work and workplaces, particularly as they were changing as a result of the introduction of automation technologies: what (Tronti 2012: 124) describes as akin to "turning a light on in the factory, focusing the lens and taking a photograph in which the relations of production stood out with startling clarity'.

Panzieri argued that the political party was an 'educator which needed to be educated' (un educatore che devere essere educato), with class struggle the location of its learning (Panzieri 1973: 202). While he argued that inquiry was a 'great tool' for 'serious political training' (Panzieri 2006), this contrasted markedly with the Gramscian view on the leading role of the party in providing workers' education and supporting what Gramsci had termed 'organic intellectuals' working under the guidance of the revolutionary party (Mayo 2010: 28). For Panzieri, a theoretical invigoration of Marxist theory would accompany the political renovation of the labour movement in ways that were specific to the Italian context, and central to this was a model of 'workers' inquiry' (l'inchiesta operaia) (articulated with particular clarity at a seminar in 1964, only a few weeks before his death, and then published in Quaderni Rossi Issue 5 and then in Panzieri 1994b).

Panzieri wrote that:

... changes of the working class need to be seen in the light of a reconfiguration of the relations established between workers and technicians and the emergence of new roles and class compositions. (Panzieri 1994b: 126)

How activists, and specifically those wishing to implement workers' inquiry, could best respond to these changes was a focus for debate within operaismo and a range of different strategies are reflected in the pages of Quaderni Rossi (again, for detailed discussion of the political roots of these differences, see Wright 2002). Panzieri argued that '... we can use [bourgeois] sociology and criticize it for its limitations, as Marx did with classical political economy' (Panzieri 1994b: 123). Using 'Weberian methodology mixed with the politics of Marxist analysis' (Tronti 2012: 124; see also Farris 2011) operaist inquiries included first-hand accounts of work and political activity from factories; analyses of the restructuring of the production process; critical assessments of management strategies and union demands; and documentary analyses of company papers, contracts and media coverage. These inquiries often began not in social or political theory but were instead 'hot inquiry' (inchiesta a caldo) stemming from the 
situated, subjective experiences of workers who found themselves facing additional demands from employers, the loss of benefits or pay cuts, or the intrusion of work into other aspects of their social lives (Panzieri 1994a: 126).

While Panzieri acknowledged that 'the kind of inquiry we are planning to carry out already features qualities that lie outside of the framework of contemporary sociology' (Panzieri 1994b: 123), there were disagreements as to how useful existing sociological methods could be in the context of workers' inquiry. For Romano Alquati, who took issue with the approaches of Panzieri, Rieser, and others within Quaderni Rossi, sociology could be, at best, a first step towards a novel and militant collaboration between workers and researchers which he described as conricerca or 'co-research'. Alquati also distinguished co-research on the grounds that much workers' inquiry was short-term in nature rather than contributing to a longer term programme and a lasting disposition towards inquiry or research amongst workers, who, he suggested 'entrust[ed] the effective use of the acquired knowledge to a political agency typically different from the team that conducted the research' (Alquati 2019: 472). Workers' inquiries might be elements in a programme of co-research, he argued, but the two did not coincide.

Alquati is perhaps best known for two major studies, one of workers at FIAT, and the other of workers on the assembly-lines and in the workshops of Olivetti. Tracing the evolution of Alquati's thinking through these two examples and then beyond to his later work, Wright (2002) and Haider and Mohandesi (2013) describe the development of Alquati's view that technological recomposition (changes in the nature of work) and social recomposition (changes in the nature and distribution of the workforce) meant that new theorizations and new forms of political action would be necessary. These necessitated new models of inquiry that positioned theorization as a radicalizing practice, rather than an exercise in the application of existing sociological or political theory.

Alquati's writings are dense and wide-ranging (Sacchetto et al. 2013 describe his work as an attempt to develop a 'new social science') but it is possible to identify within them a number of key elements. The first is a shift from thinking about workers as subjects, and rather as active subjectivities playing a leading role in the envisioning and realization of social change, and critically in asking what role work should and could play. Alquati characterized his own role as a mediator of this transition as involving 'development and clarification' of questions that asked 'fundamentally, what does FIAT give me?' into 'what different things can I hope for in a society dominated by businesses like FIAT?' (Alquati 1975: 38).

Second, there is a focus on the relationship between workers and new technologies. What is particularly noteworthy here is that Alquati articulated arguments that go beyond simplistic notions of machinery as extending and enhancing, or alternatively replacing or disempowering, workers. In analysis that presages much later sociomaterial theorisations, he described the complex assemblages of human and nonhuman in new production processes. Furthermore, he examined the ways in which processes of automation are conceptualized and the language used by both managers and workers in relation to new technologies and the work in which they played a part. In his study of Olivetti's workshops, he noted that the dominant language used was still that of the artisan with their tools, while the 'machinery' involved was actually conveyor-belt assembly lines. This involved different forms of labour, different 
relationships to technology, and (in operaist terms) distinctively different patterns of technical composition. In turn, management concerns were increasingly related to efficiency and assembly speed, rather than workers' skill or craftsmanship (Alquati 1975: 81-162).

Third, Alquati also recognized the importance of information, the technologies associated with its collection and management, and its role in surveillance, control, and asymmetrical power relations (for a detailed discussion see Pasquinelli 2015). As well as recognizing how information could be quantified and commodified, he distinguishes 'control information' related to production and performance, from the 'operational information' that represents the collective knowledge and embodied practice of workers themselves and highlights the role of managers in translating this practice into measures and targets (Alquati 1975: 113-114). The context here might have been workshop production lines, but this distinction can be identified in many other contexts where target-setting and management 'datafication' of practice is the norm.

Alquati was also interested in issues around the spatial distribution of work and the mobility of workers, which was becoming increasingly commonplace. He drew attention to the growing numbers of migrants from the south of Italy and beyond who were being recruited into new industries and who, accordingly, had different patterns of class composition and political allegiance from workers in giant 'city-factories' like FIAT. In many cases, these workers still identified with their former lives, home towns or identity as 'peasants', while still being described (and describing themselves) as (for example) 'Olivetti types' ('olivettianni'): even if in fact they did not work within the Olivetti factory itself and were in fact precariously employed in a workshop run by a company subsidiary or supplier (Alquati 1975: 97). That said, his focus was still largely on workplaces themselves, and his work pays less attention to other aspects of the social factory, the role of domestic labour, and family relations, than do some of his contemporaries (Williams 2013).

There are parallels between the foregoing themes in Alquati's work and issues in many contemporary work environments, including educational settings. But what is perhaps of greatest interest is his model of 'co-research' (conricerca) not only to document changing workers' experience, but as a form of political activism.

\section{The Character of Co-research}

The most comprehensive accounts of Alquati's co-research, in addition to his studies of FIAT and Olivetti, are a series of lecture notes published as Per Fare Conricerca, in 1993 and then a discussion of the differences between workers' inquiry in general and co-research published in 1994 (Alquati 1994 translated into English in Alquati 2019).

Co-research, according to Alquati, was:

... not just a question of solving problems; but of initiating research into a metaproblem in a certain way [in order to] re-establish the existing equilibrium and develop a further counter-itinerary, with a kind of counter-planning that is flexible and always on the move. Nomadic, but with a degree of design, a great purpose, and a strategic objective (Alquati 1993: 12-13). 
The purpose of such inquiry was not only to address immediate concerns within the workplace; it also represented instead a form of activism which developed workers' abilities to understand and challenge the mechanisms of control and alienation within workplaces, and either to promote less alienating and more democratic alternatives, or to extricate themselves entirely from them. These involved workers becoming activistresearchers, able to operate 'within and against' existing organizations (Alquati 1993: 15).

Rather than drawing, alongside Marx, on Weber, like some of his contemporaries, Alquati was influenced by radical history and philosophy of science; citing the work of Yehuda Elkana and Paul Feyerabend, he argued that it was important to recognize the power of the scientific methods and rhetoric, and to learn to appropriate and develop 'counter-uses' (contro-usarle) for these (Alquati 1993: 26), challenging the ways in which inquiry, and particularly scientific inquiry, was aligned with capitalism. This often involved starting from the same point as managerialist accounts and critiquing these, primarily by combining and counterpointing these with the perspectives of workers in order to generate alternative interpretations, hypotheses and courses of action. 'The first objective' he wrote 'was to discard the hard rind (la scorza dure) of official myths and commonplaces, through which the worker, isolated and powerless in the face of a highly organized boss, rationalized their own desperate situation' (Alquati 1975: 92). An early task in co-research was therefore to clarify the meanings of terminology and the generation of 'dictionaries' as a basis of a common language for analysis, communication and dissemination (Alquati 1993: 79).

In Per Fare Conricerca, Alquati drew on Herbert Simon's The New Science of Management Decision (Simon 1977) which had been translated into Italian in 1988. Alquati acknowledges Simon's range of expertise and in particular his insights into the role of information technologies and other workplace innovations, describing him as the 'new Taylor of contemporary, neo-modern capitalism' (Alquati 1993: 39). He then presented a reconstruction of Simon's decision-making approach to innovation, using it as a basis for a model of co-research in which the perspectives and experiences of workers are used to construct counter-hypotheses and alternative interpretations to those which might emerge from a management inquiry following Simon's heuristic problem-solving and decision-making approaches.

What this meant in practice was extensive participant observation conducted by workers and informed by social anthropological approaches (Alquati 1993: 95-100); in-depth interviews with an emphasis on interviews focused around specific practices, artefacts, documents, or events (1993: 107-108); and the compilation of diaries, autobiographies - including multimedia content (1993: 112-113). Alquati attached great importance to the collection of autobiographies through the use of interlocutors (although he also identified a need to train additional interlocutors capable of guiding and supporting the construction of these accounts). Autobiographical accounts provided a vital means of exploring the subjective experience of processes of workplace and social transformation, encapsulating the relations between technical, social and political composition: 'between the person in their processes, their personality, and their context' (1993: 113).

But there was no hierarchy of research methods implicit in co-research: neither 'scientific' approaches nor worker-authored texts were particularly privileged, the latter marking a departure from earlier workers' inquiries. Alquati made no apologies for 
drawing, albeit selectively, on the methods of science and management, arguing that the appropriateness and value of any inquiry method was instead to be measured in terms of its potential to represent worker perspectives and in the political results it achieved (Alquati 1994). Vital for the assessment of the value of co-research were processes of diffusion and validation of findings, analyses and proposals (Alquati's 'counter-itineraries') by the subjects of the research themselves. What co-research required was 'a practical (more than just empirical) verification of the validity of the hypotheses and of the way in which they contributed to produce new knowledge from within the practice of transformation' (1993: 53). As one might expect, Alquati's position was that it was the contribution made to political programmes that was the primary measure of the value of any co-research activities.

Alquati's co-research, then, differed from other workers' inquiry in its scope, its duration, and in how it might be initiated. While 'hot inquiry' inspired by a particular workplace struggle might set in train a more expansive programme of co-research, there was the risk that it would be too narrowly focused and would have neither a lasting impact, nor spread beyond the local context - a concern familiar in teacher research and particularly within the action research tradition. What Alquati hoped to promote were lasting dispositions towards critical inquiry. He describes these as 'meta-methods' (1993: 27); the development of programmes not just of co-research but counterresearch; and of the counter-institutions and infrastructures to enable them. As Roggero (2014: 518) suggests, co-research might well be initiated in 'tepid' areas, and in doing so might involve inquiry into why particular issues were not currently the focus of antagonism or activism and exploration of the processes by which such issues had become commonplace and uncontentious.

While co-research might share some of its approaches with management science, the purpose was not to develop reductionist models of workers and workplaces, nor to develop a singular, but equally reductive Marxist counter-model. Rather, its purpose was to construct viable alternatives, informed by the diverse experience of workers, to challenge managerialist assumptions and contribute to radical new programmes. For Alquati, Marx's 'general intellect' would emerge in the form of networks of classconscious, connected workers able to plan and undertake self-directed inquiry and to trouble existing theory and practices through the multiplication of perspectives and subjectivities.

As an aside, it is interesting to consider how contemporary post-operaist inquiries of the kinds mentioned above measure up to Alquati's expectations of co-research. The distinction he draws between short-term workers' inquiries and the emergence of longer term programmes of co-research is relevant here. While contemporary workers' inquiries have addressed issues in specific areas of work, there have been, as yet, few programmes of sustained co-research: although these are beginning to emerge with journals such as Notes from Below in the UK, transnational networks of workers undertaking inquiry in specific sectors, and emerging independent trades and social unions providing means of coordination and diffusion. This has contributed to the reestablishment of connections between workplace inquiry and other post-operaist and autonomist inquiry and activism, most notably the autonomist feminist movement that since the 1960's has explored and elaborated the essential role under capitalism of domestic and reproductive labour (see for example Della Costa and James 1972; Federici 1975). 


\section{Educational Inquiry, Automation, and Datafication}

What then are the implications and possibilities for operaist approaches and specifically for Alquati's model of co-research in educational inquiry? And furthermore, how might they contribute to an emerging research agenda based on ideas about the postdigital in education?

A number of the key concerns of operaismo are relevant to education and educational workers: notably the political positioning of teachers, given changes in class structures and the role of unions and teacher organizations; and precarity as an aspect of working life and social experience given that this has become more common in professions such as teaching (Means 2019). Hall (2014) discusses the relevance of later autonomist theorizing around the social factory, cognitive capitalism and the general intellect to education, particularly educational technologies. This article, however, will concentrate on the issue of the automation of educational environments and processes, and the bearing that these changes have had on teacher practice and inquiry. Arguably, the rapid 'datafication' of education represents the most obvious and pervasive way in which the 'fourth industrial revolution' is currently manifested in educational settings, and particularly in schools (higher education, with its closer associations with changing forms of work, automation, and the 'employability' agenda, experiences it in other ways (Carmichael 2019). If Dyer-Witheford's (1999) assessment of the potential of operaismo and autonomism to offer a counter-interpretation of the information revolution is correct, then it may also offer alternatives to dominant ideas about the relationships between teachers' practice, technology, data and educational outcomes.

The global 'neoliberal' project to reorganize societies and social relations has challenged the notion of education 'as a public good and public sector, and as an intrinsic element of the state-civil society social contract' (Robertson 2007: 12) and has led to providers of early childhood care, schools, colleges, and universities being reconceptualised as businesses subject to market forces. This, Ball has argued, has led educational practitioners being required to '[set] aside personal beliefs and commitments and live an existence of calculation' in response to targets, indicators, and evaluations of themselves and those in their charge (Ball 2003: 215). This been accompanied by the preferential funding of initiatives which are outcome-oriented and 'evidence based' and aligns with a view that the concern of educational inquiry is to inform and respond to governments' national agendas, particularly those that are concerned with neoliberal priorities such as workforce development or the achievement and maintenance of competitive advantage in global markets (Johanningmeier and Richardson 2008). This is despite the danger, highlighted by Biesta (2007), that this may constrain educational inquiries by legitimizing only those that align with a dominant discourse of targets, standards and external evaluation criteria. Leat et al. (2015) describe how there is a 'strong gravitational pull' towards school effectiveness research and measurable assessment outcomes. Jones and Stanley (2010) go further and echo the argument made by Ball (2003) that neoliberalism and performativity in education engender tensions, inner conflicts and inauthenticity. Similarly, Elliott (2012) argues that, rather than being sensitive to political and policy contexts, seeing the curriculum and its accompanying discourses as a legitimate focus for inquiry, and having the potential to initiate exploration of significant 
epistemological and ontological issues, much teacher inquiry has become dominated by questions of how best to address pre-determined educational outcomes.

The shift towards teacher inquiry framed by predetermined and measurable outcomes is closely aligned with, and subordinate to, an enthusiasm on the part of policy makers and educational managers for evidence-based practice and is accompanied by increasing 'datafication' of educational planning, assessment of learners, and evaluation of the effectiveness of educational practice (Bradbury and Roberts-Holmes 2017; Smith 2017). This has been discussed in the context of 'big data' (Williamson 2017); and identified as an aspect of a broader tendency towards oversimplification of complex social settings (Couldry and Yu 2018). This, it is argued, means that pedagogical practice and the experience of learners, the competence of teachers, and the efficacy of pedagogical practices become framed by data (Roberts-Holmes 2015; Bradbury 2019), with a risk that this supports the discursive construction of the 'ideal child' (Willson 2018). What this also means for teachers and learners alike is a pattern of constant and real-time surveillance of individual and aggregated data, leading to what Bradbury et al. (2018) describe as the 'hypergovernance' of educational environments and processes.

Stevenson argues that such hypergovernance means that the generation, aggregation, and making of decisions based on data that are 'increasingly detached from supporting learning and [are] much more concerned with the management of teacher performance' (Stevenson 2017: 537). This aligns closely with the distinction made by Alquati in relation to managerial 'control information' as opposed to that which reflects the knowledge and judgement of, in this case, teachers and other educational workers, whose practice then becomes defined in terms of performance against targets. Following Ball (2003), Stevenson traces how this is enacted in the self-regulation of teachers as performative subjects, and then draws on studies of social movements and the ways in which collective resistance develops, often in response to specific issues. He highlights the importance of 'bringing the ideas back in' to educational debates through the identification of problems and then 'speaking back': offering re-framings and alternatives to be counterposed against those arising from the dominant rhetorics of management and datafication (Stevenson 2017: 551). This link to social movements is of interest given their associations with autonomist theorizing, as is the idea that specific issues may be a trigger for resistance: there are echoes here of Panzieri's 'hot inquiry' here, and indeed there have been campaigns by teachers, parents and students around issues related to datafication. In the UK, for example, there has been organized resistance to the collection of specific data about pupils in the annual school census; around 'baseline' testing of children on their entry into the school system; and about the introduction of biometric scanning of children.

These developments are worthy of analysis in terms not only of the adoption (or non-adoption) of specific technologies, or the datafication of particular aspects of educational practices. Following Alquati's model of co-research, it becomes necessary to understand what motivates these innovations, and to explore in detail their impacts on the practice, relationships and identities with which they are co-constituted and 'interwoven'. Processes which, for example, involve early years teachers monitoring young children's progress against developmental and learning outcomes and recording these using tablet computers equipped with 'target tracking' software do not simply automate existing paper-based processes: in Alquati's terms, they translate the 
'operational information' of pedagogical practice into 'control information' that is aggregated and used to monitor performance at multiple levels. But even beyond this, such automation changes the relationships amongst those involved and, most critically, those between teachers and learners. Just as the workers at Olivetti with whom Alquati worked struggled to make sense of their evolving roles, teachers in such contexts need to be enabled to better understand their changing positioning in contemporary, datafied and performative educational systems. Alongside developing critical understandings of those systems through structured investigation (and, once again, following Alquati) reflective, focused and autobiographical inquiry is needed: not constrained by managerial decision-making approaches and normative notions but capable of critiquing and troubling existing pedagogical practices. And following from these, as Alquati described, participants may extend their inquiries beyond the specificities of their workplaces to broader questions about their own professional identities; issues of surveillance, precarity and security; and the role of the school and of schooling in the immediate community and society more widely.

It is from such co-research activities that potential points of resistance, and the opportunities to 'speak back' envisaged by Stevenson, emerge; but it is also clear that such co-research is intrinsically postdigital in character. Any postdigital teacher inquiry cannot limit itself to the exploration of the efficacy of new technologies, nor simply offer critiques of automation or datafication, but instead needs to explore the impact these have on relationships, identities and communities. To go further, I would argue that these are the very kinds of issues to which any programme of postdigital research must attend, and Alquati's approaches provide a useful theoretical framing and guide for such a programme.

\section{Educational Inquiry and Critical Data Literacies}

Inquiry into the nature and impacts of datafication requires a level of understanding of the processes involved, but the dominant rhetoric of 'evidence-informed' practice in education also demands that teachers and other involved in educational inquiry develop 'data literacies'. So just as Alquati encouraged workers to engage critically with management theory and processes in order to understand their workplaces, the use of data (and the concept of data literacies), becomes a both a contested field and a focus of further co-research.

Recent work on digital literacies has argued that they are multiple and situated (Lankshear and Knobel 2008; Gillen and Barton 2010) and are developed through discourse and digital production (Buckingham 2006). More recently, Gourlay and Oliver have advanced a socio-material view of digital literacies aligning, once again, with inquiry oriented towards unweaving and disentanglement of associations rather than evidence-based determination of 'what works' or definition of competences (Gourlay and Oliver 2013; Gourlay and Oliver 2016). Definitions of the more specific idea of data literacy, however, have tended to revert to focus on technical skills and evidence-based decision-making (Calzada Prado and Marzal 2013; Mandinach and Gummer 2013). This is a conceptualization of data literacy that aligns closely with the idea of teachers as evidence-informed practitioners as envisaged by Stoll et al. (2018). More recently, concerns with personal privacy (including that of children) have been 
reflected in models of data literacy which are concerned with making choices about personal data sharing and resisting its commodification (McCosker 2017; Pangrazio and Selwyn 2018). Such accounts are characterized by Milan and Van der Velden (2016) as 'reactive'. It is necessary to go beyond these immediate concerns, they suggest and develop deeper understandings of the role of data in mediating interactions between individuals, establishing and reproducing power relationships; and providing lenses through which see the world around us.

A more politicized, and, in Milan and Van der Velden's terms, a more 'proactive' vision of what might constitute 'critical data literacies' (in the plural) recognizes that data, like the tools and methods used to generate, manipulate and represent them, are socially constructed and ideologically shaped. In educational settings, this would not just involve arguing that collection of learners' personal data is educationally flawed and therefore that 'datafication' should be reduced, but rather exploring how it is ideologically driven and what its wider ramifications might be. Milan, like Stevenson, looks to social movement theories for ideas of what resistance and activism in the context of data might involve, and points to a history of activists creatively appropriating and repurposing both analogue and digital technologies for radical and emancipatory ends (Milan 2013). Again, we find parallels here with operaist and autonomist writings which argue that patterns of enclosure and appropriation need to be coresearched in order to inform programmes of counter-research, counter-appropriation or outright refusal to participate; and once again, with a postdigital orientation towards understanding data practices, rather than defining data literacies in terms of competences and outcomes.

\section{Conclusions: Co-research and Postdigital Education}

The case for postdigital inquiry in education is compelling: to think in terms of the digital and non-digital, or the offline and online, as discrete, now makes little sense. However, to assume that the digital has been seamlessly integrated into educational practice ignores that fact that many of the socio-technical assemblages of the educational landscape uncomfortable juxtapositions: complex, contested, and highly politicized. In order to challenge the performative rhetorics of 'evidence-informed' and 'data-driven' education, any models of teacher inquiry and development need to be able to engage deeply with these complexities and explore how new technologies, automation and datafication are playing out in practice.

The benefits of these technologies, automation, and datafication have been differentially distributed and have contributed to new patterns of quantification, surveillance, deskilling and precarity. These are the issues that any radical positioning of the postdigital needs to address in its theorizing and the models of inquiry it pursues. It has a rich heritage on which to draw if it is to offer not just an interesting analytic lens, but rather a way of framing understandings of multiple subjectivities, complex social assemblages and patterns of class identification and professional formation as well as providing guides and models for inquiry and resistance.

If we consider the issue from another angle: educational inquiry, and teachers who wish to undertake those inquiries, must engage with postdigital framings and approaches in order to make sense of the rapidly changing nature of their work. The 
operaists may have developed their approaches in response to the different and specific contexts in which they operated, but they too were driven by a need to understanding their changing relationships with technologies, and as such their writings provide a useful repertoire of theoretical and practical strategies and models of inquiry for any programme of postdigital educational inquiry. Romano Alquati's conception of coresearch in particular offers much that aligns with existing models of educational inquiry, while offering distinctive approaches that were developed in response to rapidly changing, and for the time, technologically advanced, working environments, but which are equally relevant (and perhaps even more relevant and widely applicable) to contemporary situations.

At a time when new technologies, social formations, and patterns of work are emerging, the theory and practice of operaismo, workers' inquiry, and co-research are once again attracting interest; there are fruitful overlaps and intersections between these and emerging ideas about the postdigital in education that can surely contribute to a radical, counter-hegemonic, and generative programme of educational inquiry.

Acknowledgements Acknowledgements are due to Frances Tracy, Will Stronge, and Holly Rigby for the useful discussions that took place during the writing of this article, and to the reviewers of an earlier version of this paper.

\section{Compliance with Ethical Standards}

Conflict of Interest The author declares that they have no conflict of interest.

Open Access This article is distributed under the terms of the Creative Commons Attribution 4.0 International License (http://creativecommons.org/licenses/by/4.0/), which permits unrestricted use, distribution, and reproduction in any medium, provided you give appropriate credit to the original author(s) and the source, provide a link to the Creative Commons license, and indicate if changes were made.

\section{References}

Alexenberg, M. (2011). The future of art in a postdigital age: from Hellenistic to Hebraic consciousness (2nd edition). Bristol: Intellect.

Alquati, R. (1975). 'Sulla Fiat' e Altri Scritti. Milan: Feltrinelli.

Alquati, R. (1993). Per fare conricerca. Turin: Calusca Edizione.

Alquati, R. (1994). Cultura, formazione e ricerca. Turin: Velleità Alternative.

Alquati, R. (2019). Co-research and worker's inquiry. South Atlantic Quarterly, 118(2), 470-478. https://doi. org/10.1215/00382876-7381382.

Ball, S. (2003). The teacher's soul and the terrors of performativity. Journal of Education Policy, 18(2), 215228. https://doi.org/10.1080/0268093022000043065.

Biesta, G. (2007). Why "what works" won't work: evidence-based practice and the democratic deficit in educational research. Educational Theory, 57, 1-22. https://doi.org/10.1111/j.1741-5446.2006.00241.x.

Bradbury, A. (2019). Datafied at four: the role of data in the 'schoolification' of early childhood education in England. Learning, Media and Technology, 44(1), 7-21. https://doi.org/10.1080/17439884.2018.1511577

Bradbury, A., \& Roberts-Holmes, G. (2017). The datafication of primary and early years education: playing with numbers. New York: Routledge.

Bradbury, A., Lee, S., \& Roberts-Holmes, R. (2018). Hyper-governance and datafication in early years education. BERA Bites, 1, 13-16. 
Brophy, E. (2004). Italian operaismo face to face: a report on the 'Operaismo a Convegno' conference, 1-2 June 2002 - Rialto Occupato, Rome, Italy. Historical Materialism, 12(1), 277-298. https://doi. org/10.1163/156920604773564096.

Buckingham, D. (2006). Defining digital literacy: what do young people need to know about digital media? Digital Kompetense, 1, 263-276.

Calzada Prado, J., \& Marzal, M. Á. (2013). Incorporating data literacy into information literacy programs: core competencies and contents. Libri, 63(2). https://doi.org/10.1515/libri-2013-0010.

Cant, C. (2019). Riding for Deliveroo: resistance in the new economy. Cambridge: Polity Press.

Carmichael, P. (2019). Refusal of Work, Liberation of Time and the Convivial University. In M. Peters, P. Jandrić, \& A. Means (Eds.), Education and Technological Unemployment (pp. 236-278). Dordrecht: Springer.

Couldry, N., \& Yu, J. (2018). Deconstructing datafication's brave new world. New Media \& Society, 20(12), 4473-4491. https://doi.org/10.1177/1461444818775968 .

Cuninghame, P. (2010). Autonomism and social movements. WorkingUSA: The Journal of Labor and Society, 13(4), 451-464.

Curcio, A. (2014). Practicing militant inquiry: composition, strike and betting in the logistics workers struggles in Italy. Ephemera, 14(3).

Delfanti, A. (2018). Amazon is the new FIAT. Notes from Below, 3. https://notesfrombelow. org/article/amazon-is-the-new-fiat. Accessed 28 November 2019.

Della Costa, M., \& James, S. (1972). The power of women and the subversion of the community. Bristol: Falling Wall Press.

Dyer-Witheford, N. (1999). Cyber-Marx: cycles and circuits of struggle in high-technology capitalism. Chicago, IL: University of Illinois Press.

Dyer-Witheford, N., Kjøsen, A. M., \& Steinhoff, J. (2019). Inhuman power: artificial intelligence and the future of capitalism. London: Pluto Press.

Elliott, J. (2012). Teaching controversial issues, the idea of the 'teacher as researcher' and contemporary significance for citizenship education. In J. Elliott \& N. Norris (Eds.), Curriculum, pedagogy and educational research: the work of Lawrence Stenhouse (pp. 84-105). London: Routledge.

Farris, S. R. (2011). Workerism's inimical incursions: on Mario Tronti's Weberianism. Historical Materialism, 19(3), 29-62. https://doi.org/10.1163/156920611x594731.

Federici, S. (1975). Wages against housework. Bristol: Falling Wall Press.

Freire, P. (1998). Pedagogy of freedom: ethics, democracy and civic courage. Lanham, MD: Rowman \& Littlefield.

Gillen, J., \& Barton, D. (2010). Digital literacies. London: London Knowledge Lab/TLRP.

Giroux, H., \& McLaren, P. (1987). Teacher education as a counterpublic sphere: radical pedagogy as a form of cultural politics. Philosophy and Social Criticism, 12(1), 51-69. https://doi.org/10.1177 /019145378701200103.

Gourlay, L., \& Oliver, M. (2013). Beyond 'the social': digital literacies as sociomaterial practice. In R. Goodfellow \& M. Lea (Eds.), Literacy in the Digital University: critical perspectives on learning, scholarship and technology. London: Routledge.

Gourlay, L., \& Oliver, M. (2016). It's not all about the learner: reframing students' digital literacy as sociomaterial practice. In T. Ryberg, C. Sinclair, S. Bayne, \& M. de Laat, (Eds.), Research, boundaries, and policy in networked learning (pp. 77-92). Dordrecht: Springer. https://doi.org/10.1007/978-3-31931130-2 5.

Haider, A., \& Mohandesi, A. (2013). Workers' inquiry: a genealogy. Viewpoint, 27 September. https://www. viewpointmag.com/2013/09/27/workers-inquiry-a-genealogy/. Accessed 28 November 2019.

Hall, R. (2014). The implications of autonomist Marxism for research and practice in education and technology. Learning, Media and Technology, 40(1), 106-122. https://doi.org/10.1080 /17439884.2014.911189.

Hall, M. (2018). Will apps help carers find decent work? New Economics Foundation, 22 June. https://neweconomics.org/2018/06/will-apps-help-carers-find-decent-work. Accessed 28 November 2019.

Hardt, M., \& Negri, A. (2001). Empire. Cambridge, MA: Harvard University Press.

Hardt, M., \& Negri, A. (2006). Multitude: war and democracy in the age of empire. Harmondsworth: Penguin.

Jandrić, P., Knox, J., Besley, T., Ryberg, T., Suoranta, J., \& Hayes, S. (2018). Postdigital science and education. Educational Philosophy and Theory, 50(10), 893-899. https://doi.org/10.1080 /00131857.2018.1454000.

Johanningmeier, E. V., \& Richardson, T. R. (2008). Educational research, the national agenda, and educational reform: a history. Charlotte, NC: Information Age Publishing. 
Jones, M., \& Stanley, G. (2010). Collaborative action research: a democratic undertaking or a web of collusion and compliance? International Journal of Research and Method in Education, 33(2), 151-163. https://doi.org/10.1080/1743727X.2010.484549.

Lankshear, C., \& Knobel, D. (2008). Digital literacies: concepts, policies and practices. New York: Peter Lang.

Leat, D., Reid, A., \& Lofthouse, R. (2015). Teachers' experiences of engagement with and in educational research: what can be learned from teachers' views? Oxford Review of Education, 41(2), 270-186. https://doi.org/10.1080/03054985.2015.1021193.

Mandinach, E. B., \& Gummer, E. S. (2013). A systemic view of implementing data literacy in educator preparation. Educational Researcher, 42(1), 30-37. https://doi.org/10.3102/0013189x12459803.

Marx, K. (1973). Grundrisse: foundations of a critique of political economy. Harmondsworth: Penguin.

Mayo, P. (2010). Antonio Gramsci and his relevance to the education of adults. In P. Mayo (Ed.), Gramsci and educational thought. Wiley-Blackwell: Chichester.

McCosker, A. (2017). Data literacies for the postdemographic social media self. First Monday, 22(10). https://doi.org/10.5210/fm.v22i10.7307.

Means, A. (2019). Precarity and the precaritization of teaching. In M. Peters (Ed.), Encyclopedia of teacher education. Singapore: Springer.

Milan, S. (2013). Social movements and their technologies: wiring social change. Basingstoke: Palgrave Macmilllan.

Milan, S., \& Van der Velden, L. (2016). The alternative epistemologies of data activsm. Digital Culture and Society, 2(2), 57-74. https://doi.org/10.14361/dcs-2016-0205.

Murray, J. M. (2014). The shame of servers: inquiry and agency in a Manhattan Cocktail Lounge. Ephemera, 14(3), 431-455. http:/www.ephemerajournal.org/sites/default/files/pdfs/contribution/14-3murray_0.pdf. Accessed 28 November 2019.

Negri, A. (1978). La classe ouvriere contre I'Etat. Paris: Editions Galilee.

Negri, A. (2005). The politics of subversion: a manifesto for the 21st century. Cambridge: Polity Press.

Negri, A. (2018). From the factory to the metropolis. Cambridge: Polity Press.

Palazzo, D. (2014). The social factory in postwar Italian radical ought from Operaismo to Autonomia. $\mathrm{PhD}$ Dissertation. New York: City University of New York.

Pangrazio, L., \& Selwyn, N. (2018). 'Personal data literacies': a critical literacies approach to enhancing understandings of personal digital data. New Media \& Society, 21(2), 419-437. https://doi.org/10.1177 /1461444818799523.

Panzieri, R. (1973). Scritti 1956-1960. Milan: Lampugnani Nigri.

Panzieri, R. (1994a). Spontaneità e Organizzazione: Gli anni dei "Quaderni Rossi" 1959-1964. Pisa: Biblioteca Franco Serantini.

Panzieri, R. (1994b). Uso socialista dell'inchiesta operaia. In S. Merli (Ed.), Spontanteità e Organizzazione: Gli anni dei 'Quaderni Rossi' 1959-1964 (pp. 119-128). Milan: Edizioni BFS.

Panzieri, R. (2006). Socialist uses of workers' enquiry. http://eipcp.net/transversal/0406/panzieri/en. Accessed 28 Nov 2019.

Pasquinelli, M. (2015). Italian Operaismo and the information machine. Theory, Culture and Society, 32(3), 49-68. https://doi.org/10.1177/0263276413514117.

Roberts-Holmes, G. (2015). The "datafication" of early years pedagogy: "If the teaching is good the data should be good,and if there's bad teaching there is bad data". Journal of Education Policy, 30(3), 302315. https://doi.org/10.1080/02680939.2014.924561.

Robertson, S. (2007). 'Remaking the world': neo-liberalism and the transformation of education and teachers' labour. In L. Weis \& M. Compton (Eds.), The global assault on teachers, teaching and their unions (pp. 11-27). New York: Palgrave.

Roggero, G. (2014). Notes on reframing and re-inventing co-research. Ephemera, 14(3), 515-523. http://www.ephemerajournal.org/sites/default/files/pdfs/contribution/14-3roggero.pdf. Accessed 28 November 2019.

Roggero, G., Pozzi, F., \& Borio, G. (2002). Futuro anteriore: Dai Quaderni Rossi al movimento globale. Ricchezze e limiti dell'operaismo italiano. Roma: DeriveApprodi.

Ryberg, T., Davidsen, J., \& Hodgson, V. (2018). Understanding nomadic collaborative learning groups. British Journal of Educational Technology, 49(2), 235-247. https://doi.org/10.1111/bjet.12584.

Sacchetto, D., Armano, E., \& Wright, S. (2013). Coresearch and counter-research: Romano Alquati's itinerary within and beyond Italian radical political thought. Viewpoint, 27 September. https://www.viewpointmag. com/2013/09/27/coresearch-and-counter-research-romano-alquatis-itinerary-within-and-beyond-italianradical-political-thought/. Accessed 28 November 2019. 
Scholz, T. (2017). Uberworked and underpaid: how workers are disrupting the digital economy. Cambridge: Polity Press.

Schwab, K. (2016). The fourth industrial revolution. London: Penguin.

Simon, H. (1977). The new science of management decision. Upper Saddle River, NJ: Prentice Hall.

Smith, R. (2017). The emergence of the quantified child. Discourse: Studies in the Cultural Politics of Education, 38(5), 701-712. https://doi.org/10.1080/01596306.2015.1136269.

Srnicek, N. (2017). Platform Capitalism. Cambridge: Polity Press.

Stevenson, H. (2017). The "Datafication" of teaching: can teachers speak Back to the numbers. Peabody Journal of Education, 92(4), 537-557. https://doi.org/10.1080/0161956x.2017.1349492.

Stoll, L., Greany, T., Coldwell, M., Higgins, S., Brown, C., Maxwell, B., et al. (2018). Evidence informed teaching: self-assessment tool for teachers. London: Chartered College of Teachers.

Thoburn, N. (2003). Deleuze, Marx and politics. London: Routledge.

Tronti, M. (1962). La fabbrica e la società. Quaderni Rossi, 2, 1-31.

Tronti, M. (2010). Workerism and politics. Historical Materialism, 18(3), 186-189. https://doi.org/10.1163 $/ 146544609 \times 12537556703232$.

Tronti, M. (2012). Our operaismo. New Left Review, 73, 119-139.

Williams, E. (2013). Invisible organization: Reading Romano Alquati. Viewpoint, 26 September. https://www. viewpointmag.com/2013/09/26/invisible-organization-reading-romano-alquati/. Accessed 28 Nov 2019.

Williamson, B. (2017). Big data in education: the digital future of learning, policy and practice. SAGE Publications Ltd..

Willson, M. (2018). Raising the ideal child? Algorithms, quantification and prediction. Media, Culture \& Society, 41(5), 620-636. https://doi.org/10.1177/0163443718798901.

Woodcock, J. (2016). Working the phones: control and resistance in call centres. London: Pluto Press.

Wright, S. (2002). Storming heaven: class composition and struggle in Italian autonomist Marxism. London: Pluto Press.

Wright, S. (2007a). There and back again: mapping the pathways within autonomist Marxism. http:/libcom. org/library/there-and-back-again-mapping-the-pathways-within-autonomist-marxism-steve-wright. Accessed 28 Nov 2019.

Wright, S. (2007b). Back to the future: Italian workerists reflect upon the operaista project. Ephemera, 7(1), 270-281. http://www.ephemerajournal.org/sites/default/files/7-1wright.pdf. Accessed 28 Nov 2019. 